\title{
PENGAWETAN DAN PENGOLAHAN LIMBAH IKAN SERTA IKAN SEGAR MENJADI PRODUK YANG DAPAT MENINGKATKAN PENDAPATAN KELUARGA NELAYAN DI KELURAHAN MALABRO KOTA BENGKULU
}

\section{PRESERVATION AND PROCESSING OF FISH WASTE AND FRESH FISH THAT CAN BE INCOME GENERATING PRODUCTS FOR FISHERMEN HOUSEHOLD IN VILLAGE MALABRO BENGKULU}

\author{
Oleh: \\ Madani Hatta, Halimatusyadiah, Novita sari \\ Jurusan Akuntansi Fakultas Ekonomi dan Bisnis Universitas Bengkulu
}

\begin{abstract}
This program is a community service activities with the activity of the title is Preservation and Processing of Fish Waste and Fresh Fish that can be Income Generating Products for Fishermen Household in Village Malabro Bengkulu. This activity aims to equip the housewives of fishermen about fish preservation and processing of fish waste into products that can be sold to raise additional revenue for fishermen family in the village of Malabro. The results achieved from this activity is fishermen housewives have gained new knowledge about fish preservation and processing of fish waste into fish crackers, fishermen housewives eager and motivated to immediately apply the knowledge and skills gained from this activity, establishment of home industry by housewives of fishermen engaged in the processing of fish crackers processed fish waste, fishermen housewives have been able to preserve the fish in order to survive longer, fishermen housewives have learned how to market their product or distributed crackers they made, which has been formed a new source of income for women in the fishing village Malabro.
\end{abstract}

Keyword: Preservation, Processing, Fish Waste, Fish Crackers

\section{PENDAHULUAN}

Kekayaan laut yang melimpah ternyata tidak berkorelasi terhadap peningkatan kesejahteraan masyarakat pesisir, khususnya para nelayan tradisional. Kehidupan nelayan sering memberikan gambaran kondisi kemiskinan, kekurangan gizi, lingkungan kehidupan yang kumuh serta kehidupan prekonomian yang tidak pasti. Kondisi diatas tidak mesti terjadi jika, para nelayan dibekali pengetahuan-pengetahuan yang dapat mereka gunakan untuk mengolah sumber daya yang ada. Hal ini harus menjadi perhatian khusus bagi peneliti-peneliti maupun akademisi mengingat hampir lima puluh persen wilayah di Provinsi Bengkulu terletak di pesisir pantai. 
Salah satu kelurahan yang letaknya berbatasan langsung dengan pesisir pantai adalah kelurahan Malabro yang merupakan salah satu kelurahan yang berada di Kecamatan Teluk Segara Kota Bengkulu. Kelurahan Malabro ini memiliki jumlah Kepala Keluarga (KK) kurang lebih sebanyak 270 KK. Hampir enam puluh persen mata pencarian penduduk di Kelurahan Malabro berprofesi sebagai nelayan. Karena terletak di pesisir pantai, tentu saja kelurahan ini memiliki kekayaan laut yang melimpah pula.

Berdasarkan data yang ada di Dinas Kelautan dan Perikanan Kota Bengkulu (Anonim, 2008), bahwa Kota Bengkulu mampu menghasilkan tangkapan ikan sebanyak lebih kurang 12.200 ton/tahun, termasuk tangkapan ikan yang bersumber dari Kelurahan Malabro. Adanya kekayaan laut yang melimpah ini mendorong masyarakat dipesisir pantai Kelurahan Malabro memilih mata pencaharian sebagai nelayan. Namun demikian kehidupan para nelayan dipesisir pantai Kelurahan Malabro masih saja hidup dalam ketidakpastian prekonomian. Ketidakpastian prekonomian sering sekali dikaitkan dengan kurangnya sumber permodalan yang dimiliki para nelayan. Kekurangan modal ini dianggap penyebab terbatasnya ruang gerak masyarakat nelayan dalam peningkatan pendapatannya. Namun sebenarnya banyak cara lain yang bisa dilakukan oleh nelayan untuk memanfaatkan hasil tangkapannya tanpa harus mengeluarkan modal besar.

Salah satu usaha yang bisa dilakukan oleh nelayan dalam meningkatkan pendapatannya tanpa mengeluarkan modal yang besar yaitu dengan memanfaatkan serta memodifikasi limbah ikan dan pengawetan ikan. Selama ini ikan dikonsumsi langsung atau diolah menjadi produk olahan. Kenyataan ini telah memunculkan berbagai industri pengolahan, baik skala besar maupun kecil (Suhartini dan Hidayat, 2005). Selain menghasilkan produk olahan ikan, industri tersebut juga menghasilkan limbah ikan. Potensi ini memiliki prospek yang cerah untuk dikembangkan sebagai lahan usaha baru.

Limbah ikan dapat diolah menjadi beberapa produk olahan, seperti tepung ikan, kerupuk ikan, silase ikan, petis ikan, terasi ikan/udang, kecap ikan/udang dan pupuk organik (kompos) (Suryani, 2002). Beberapa produk olahan limbah ikan tersebut telah dikenal masyarakat dan memiliki pangsa pasar domestik yang luas. Ketersediaan bahan baku merupakan jaminan terhadap kelangsungan industri olahan limbah ikan.

Pengolahan limbah ikan dan pengawetan ikan ini dapat dilakukan oleh ibu-ibu rumah tangga di Kelurahan Malabro yang suami mereka berprofesi sebagai nelayan. Selama ini ibu-ibu yang suaminya berprofesi sebagai nelayan, cenderung memanfaatkan waktu luang mereka untuk hal-hal seperti menjaga anak-anak, mengurus rumah tangga dan menanti suami mereka dari laut. Kadang-kadang sambil menanti suami mereka dari laut, mereka hanya duduk-duduk sambil membicarakan hal-hal yang tidak penting. Oleh sebab itu, kegiatan ini dimaksudkan untuk meberikan bekal pengetahuan bagi ibu-ibu di Kelurahan Malabro agar mau berkreasi dalam memanfaatkan limbah ikan dan pengawetan ikan hasil tangkapan suami mereka.

Disamping itu dengan pengetahuan tentang pengolahan limbah ikan dan pengawetan ikan yang mereka miliki, dapat memotivasi mereka untuk membuat industri kecil-kecilan 
di rumah mereka sendiri. Dengan industri kecil-kecilan di rumah mereka sendiri, mereka masih tetap bisa menjalankan tugas pokok mereka sebagai ibu rumah tangga seperti mengasuh anak-anak serta mengurus rumah tangga mereka tanpa harus keluar rumah. Disamping itu, hasil industri kecil-kecilan tersebut dapat dijual ke toko-toko terdekat yang pada akhirnya akan menghasilkan pendapatan. Pendapatan yang dihasilkan inilah akan dapat membantu suami mereka dalam menunjang kehidupan prekonomian keluarga.

Berdasarkan uraian diatas maka permasalahan yang akan dibahas dalam kegiatan ini adalah:

1. Bagaimana meningkatkan pengetahuan, kreatifitas serta memotivasi ibu-ibu istri nelayan untuk dapat mengolah limbah ikan atau ikan segar hasil tangkapan dari suami mereka menjadi berbagai produk ikan yang bernilai ekonomis tinggi.

2. Bagaimana memotivasi ibu-ibu rumah tangga istri nelayan dapat membentuk industriindustri kecil rumah tangga (home industry) dalam hal pengolahan limbah ikan dan ikan segar yang akan menghasilkan produk yang memiliki nilai ekonomis tinggi.

3. Bagaimana memotivasi ibu-ibu rumah tangga istri nelayan untuk menciptakan sumber penghasilan baru dari penjualan produk yang dihasilkan dari pengolahan limbah ikan dan ikan segar sehingga dapat membantu perekonomian mereka.

4. Bagaimana cara pengolahan berbagai produk dari limbah ikan dan ikan segar.

5. Bagaimana cara pengemasan dan pemasaran produk olahan dari limbah ikan dan ikan segar yang telah dihasilkan oleh ibu-ibu rumah tangga istri nelayan di Kelurahan Malabro.

Tujuan yang akan dicapai dari adanya kegiatan ini adalah:

1. Sebagai sarana untuk meningkatkan pengetahuan, kreatifitas serta memotivasi ibu-ibu yang suami mereka berprofesi sebagai nelayan agar dapat memanfaatkan limbah ikan dan pengawetan ikan menjadi komoditi yang bernilai ekonomis tinggi sehingga dapat membantu perekonomian mereka.

2. Untuk menciptakan atau membentuk industri-industri kecil rumah tangga (home industry) dalam hal pengolahan limbah ikan dan pengawetan ikan yang akan menghasilkan produk dari limbah ikan.

3. Untuk menciptakan sumber penghasilan baru dari produk yang dihasilkan limbah ikan.

Manfaat yang dapat dicapai dari adanya kegiatan ini adalah:

1. Ibu-ibu istri nelayan mendapatkan pengetahuan tentang pengolahan limbah ikan dan pengawetan ikan

2. Terciptanya industri-industri kecil rumah tangga (home industry)

3. Terdapat sumber penghasilan baru dari memproduksi produk dari limbah ikan.

4. Termanfaatkannya waktu luang ibu-ibu istri nelayan. 


\section{METODE PENGABDIAN}

\section{Kerangka Pemecahan Masalah}

Untuk mencapai tujuan dari kegiatan yang telah dikemukakan diatas, maka kearangka pemecahan masalah yang akan dilaksanakan meliputi:

a. Memberikan arahan mengenai pemanfaatan sumber daya yang ada disekitar lingkungan tempat tinggal terutama berkenaan dengan hasil tangkap berupa ikan yang akan diolah menjadi berbagai produk yang mampu meningkatkan pnghasilan keluarga nelayan.

b. Memberikan pengetahuan dalam bentuk praktik langsung cara pengawetan ikan dan pengolahan limbah ikan menjadi kerupuk yang dapat dipasarkan sehingga dapat meningkatkan penghasilan keluarga nelayan

c. Diskusi dan tanya jawab berkenaan dengan cara pengawetan ikan dan pengolahan limbah ikan menjadi kerupuk yang selama ini belum mereka lakukan.

\section{Realisasi Pemecahan Masalah}

Pengawetan ikan dan pemanfaatan limbah ikan menjadi produk yang memberikan nilai tambah tersendiri merupakan kegiatan yang sangat baik dalam upaya memberdayakan ibu-ibu rumah tangga yang rata-rata suami mereka berprofesi sebagai nelayan. Kegiatan ini dilaksanakan dengan beberapa tahapan.

Tahapan awal adalah melakukan survey langsung ke lokasi kegiatan untuk melihat potensi sumber daya alam yang ada di sekitar Kelurahan Malabro Kecamatan Teluk Segara Kotamadya Bengkulu. Tahap selanjutnya mendatangi kelompok ibu-ibu nelayan setempat untuk membicarakan tentang pelaksanaan kegiatan. Kemudian tahap persiapan pelaksanaan kegiatan dengan membeli semua kebutuhan kegiatan seperti minyak goreng, plastik, tepung terigu dan lain-lain.

Tahapan selanjutnya adalah tahap pelaksanaan kegiatan dengan metode pembekalan, praktik, diskusi dan tanya jawab mengenai pengawetan ikan dan pemanfaatan limbah ikan menjadi kerupuk yang dapat dipasarkan sehingga mampu meningkatkan penghasilan keluarga nelayan. Tahap akhir adalah mengevaluasi hasil kegiatan dengan cara mendatangi kembali lokasi kegitan untuk melihat dan memastikan apakah ibu-ibu nelayan di Kelurahan Malabro Kecamatan Teluk Segara Kotamadya Bengkulu telah mempraktikkan tentang pengawetan dan pengolahan limbah ikan menjadi kerupuk yang dapat mereka pasarkan. Setelah semua tahapan selesai, barulah dilakukan tahapan pembuatan laporan kegiatan tentang pengawetan ikan dan pengolahan limbah ikan menjadi kerupuk.

\section{Khalayak Sasaran}

Khalayak sasaran yang dituju dalam kegiatan ini adalah ibu-ibu istri nelayan yang berada di Kelurahan Malabro Kecamatan Teluk Segara Kotamadya Bengkulu. Ibu-ibu istri nelayan ini kesehariannya hanya sebagai ibu rumah tangga yang mengurus anak-anak serta suami mereka. Ibu-ibu istri nelayan ini memiliki banyak waktu luang yang sebenarnya dapat digunakan untuk hal-hal yang bermanfaat. Hampir setiap hari, ibu-ibu istri nelayan 
ini hanya menggunakan waktu luang mereka untuk membicarakan sesutu yang tidak bermanfaat.

\section{Metode Yang Digunakan}

Kegiatan pengabdian pada masyarakat ini dilaksanakan dalam beberapa langkah yaitu:

a. Tahap Persiapan

1. Melihat situasi dan kondisi yang terdapat pada daerah pesisir pantai terutama keadaan ibu-ibu istri nelayan yang hanya bekerja sebagai ibu rumah tangga.

2. Melakukan konfirmasi pada aparat kelurahan untuk meminta data mengenai ibuibu istri nelayan serta meminta izin untuk melakukan kegiatan pengabdian pada masyarakat.

3. Mendatangi ketua kelompok istri nelayan yang ada di Kelurahan Malabro untuk membicarakan segala sesuatu berkaitan pelaksanaan kegiatan.

b. Tahap Pelaksanaan

1. Mengundang ibu-ibu istri nelayan untuk mendengarkan arahan dari kelurahan serta tim kegiatan ini tentang peluang-peluang usaha atau home-home industri yang dapat dilakukan untuk meningkatkan prekonomian keluarga.

2. Berdiskusi mengenai potensi yang seharusnya terbuang tapi dapat dimanfaatkan yang banyak dihasilkan dari sisa-sisa penjualan ikan berupa kepala dan insang ikan.

3. Memaparkan bagaimana cara pengawetan ikan dan mengolah limbah ikan sehingga menjadi beberapa produk seperti kerupuk ikan.

4. Menjelaskan cara pengemasan serta pemasaran produk-produk yang dibuat dari limbah ikan.

c. Tahap Evaluasi

1. Mengunjungi kembali lokasi kegiatan untuk melihat, apakah ibu-ibu nelayan telah menerapkan pengetahuan yang didapat dari kegiatan penyuluhan yang telah dilakukan oleh tim pengabdian.

2. Mendengarkan keluhan dan masukan dari ibu-ibu nelayan atas kegiatan pengolahan limbah ikan dan udang menjadi kerupuk yang telah mereka lakukan

3. Menerima masukan dari ibu-ibu nelayan tentang prospek kegiatan yang akan datang.

d. Pelaporan

1. Meminta surat keterangan pelaksanaan kegiatan pengabdian pada masyarakat kepada ketua kelompok ibu-ibu istri nelayan yang ada di Kelurahan Malabro Kecamatan Teluk Segara Kotamadya Bengkulu.

2. Mencetak foto-foto kegiatan

3. Membuat laporan pelaksanaan kegiatan. 


\section{HASIL DAN PEMBAHASAN}

Pelaksanaan kegiatan pengabdian pada masyarakat ini dilaksanakan disalah satu rumah penduduk yang berdomisili di Kelurahan Malabro. Banyak hal-hal yang positif yang dapat kami laporkan dari pelaksanaan kegiatan pengabdian pada masyarakat diantaranya:

1. Tema kegiatan pengabdian pada masyarakat yaitu tentang pengawetan ikan dan pengolahan limbah ikan sangat cocok dengan lingkungan atau monografi Kelurahan Malabro yang mayoritas penduduknya berprofesi sebagai nelayan.

2. Terdapat banyak kemudahan yang didapat oleh tim pelaksanaan pengabdian pada masyarakat terutama dalam hal perizinan untuk melaksanakan kegiatan, tempat untuk mengadakan kegiatan.

3. Respon masyarakat khususnya ibu-ibu rumah tangga dan nelayan yang begitu antusias dalam mengikuti kegiatan pengabdian, ini terlihat dari banyaknya jumlah masyarakat yang hadir.

4. Keingintahuan masyarakat tentang pengawetan ikan dan pengolahan limbah ikan menjadi kerupuk sangat tinggi, ini terlihat dari banyaknya pertanyaan yang diajukan berkenaan dengan cara pengawetan ikan dan pengolahan limbah ikan.

5. Banyaknya permintaan masyarakat khususnya ibu-ibu nelayan agar tim pengabdian sering turun ke masyarakat dalam rangka memberikan sumbang saran serta pengetahuan terutama berkaitan dengan pengolahan hasil tangkapan nelayan.

Secara umum masyarakat di Kelurahan Malabro sangat antusias dalam mempraktikkan pengetahuan dan pengalamannya dalam mengikuti kegiatan tentang pengawetan ikan dan pengolahan limbah ikan. Hasil evaluasi dan monitoring terakhir yang dilakukan oleh tim pengabdian, ternyata sudah ada ibu-ibu nelayan yang mencoba membuat sendiri kerupuk ikan dari limbah ikan, bahkan sudah ada yang mencoba memasarkan hasil olahan limbah ikan menjadi kerupuk ini ke warung-warung kecil disekitar rumah mereka. Dilihat dari kualitas produk yang telah dibuat atau dihasilkan oleh ibu-ibu nelayan, cukup bagus hanya saja pengemasannya masih sangat sederhana dan belum ada merek dagang. Namun demikian dari segi rasa sudah menunjukkan hasil yang memuaskan.

Hasil dari kegiatan ini juga sudah memenuhi harapan tim pelaksana kegiatan pengabdian pada masyarakat diantaranya:

1. Sudah mulai terbentuk usaha-usaha rumah tangga (home industry) yang bergerak dalam usaha pengolahan limbah ikan menjadi kerupuk

2. Adanya pemasaran produk kerupuk dari limbah ikan, meskipun lingkup pemasarannya masih kecil.

3. Ibu-ibu keluarga nelayan sudah mampu menghasilkan tambahan pendapatan bagi keluarga mereka dari penjualan kerupuk yang dibuat dari pengolahan limbah ikan. Namun demikian, pendapatan yang sudah dihasilkan masih relatif kecil, mengingat 
jumlah kerupuk yang dipasarkan sangat terbatas yaitu hanya pada warung-warung kecil.

4. Ibu-ibu nelayan sudah mampu berkreativitas dalam pengolahan hasil tangkapan suami mereka, yang selama ini hanya dijemur untuk dijadikan ikan asin.

5. Ibu-ibu nalayan sudah mampu memodifikasi kemasan kerupuk yang dihasilkannya dari limbah ikan menjadi berbagai macam ukuran seperti ada kemasan kerupuk yang besar harganya Rp.10.000,- per bungkus dan ada juga kemasan kerupuk yang sedang harganya Rp.5.000,- per bungkusnya.

Selain sudah memenuhi harapan tim pelaksana kegiatan, namun terdapat juga beberapa faktor penghambat yang kami temukan di lapangan diantaranya ibu-ibu nelayan belum berani dan mampu memasarkan produk kerupuk yang mereka buat ke toko-toko yang lebih besar. Hal ini disebabkan karena produk-produk yang mereka hasilkan belum ada merek dagang dan usaha yang mereka lakukan belum ada izin usahanya. Mereka belum mengetahui bagaimana cara mengurus perizinan usaha atau lebel depkes yang biasa terdapat pada merek produk. Selanjutnya faktor keterbatasan modal yang mereka miliki untuk mengembangkan usaha kerupuknya.

Hasil akhir yang bisa kami laporkan bahwa ibu-ibu nelayan di Kelurahan Malabro sangat mengharapkan agar kami mau memberikan kembali pengetahuan tentang bagaimana cara memanfaatkan udang rebon yang merupakan salah satu hasil tangkapan nelayan yang sering terbuang ketika musimnya melimpah.

\section{KESIMPULAN DAN SARAN}

\section{Kesimpulan}

Dari hasil kegiatan pengabdian pada masyarakat yang telah kami lakukan, dapat disimpulkan hal-hal sebagai beriku:

1. Dengan adanya kegiatan ini, masyarakat nelayan khususnya ibu-ibu telah memperoleh pengetahuan dan keterampilan yang memadai mengenai pengawetan ikan dan pengolahan limbah ikan menjadi produk

2. Terdapatnya sumber penghasilan tambahan bagi keluarga nelayan dari hasil produk yang telah dibuatnya dari limbah ikan, meskipun penghasilan yang didapatkan masih sedikit.

3. Terbentuknya industri-industri rumah tangga (home indutry) dalam hal pengolahan limbah ikan menjadi suatu produk, yaitu kerupuk.

4. Berkembangnya kreativitas ibu-ibu nelayan dalam hal memodifikasi produk yang dihasilkannya, terutama dalam hal pengemasan produk.

\section{Saran}

Kegiatan pengabdian pada masyarakat ini perlu ditindaklanjuti dengan memberikan bekal pengetahuan bagi ibu-ibu nalayan tentang cara mengurus perizinan usaha dan cara mendapatkan bantuan modal usaha sehingga produk yang mereka hasilkan dapat lebih 
berkembang serta dapat dijual dengan pangsa pasar yang lebih luas lagi. Selain itu perlu juga menanggapi permintaan ibu-ibu nelayan agar memberikan pengetahuan tentang pengolahan udang rebon yang selama ini hanya mereka buang jika musimnya melimpah.

\section{DAFTAR PUSTAKA}

Anonim, 2008, Dinas Perikanan dan Kelautan Kota Bengkulu, Bengkulu.

Suhartini, S., dan N. Hidayat, 2005, Olahan Ikan Segar, Trubus Agrisarana, Surabaya.

Suryani, Ani, 2002, Aneka Produk Olahan Limbah Ikan, Penerbit Penebar Swadaya, Jakarta. 